\title{
IMPLEMENTATION OF EDUCATIONAL SUPPORT FOR A PUPIL WITH DEVELOPMENTAL DISORDER IN INDIVIDUAL EDUCATION PLAN
}

\author{
Authors: \\ Jarmila Žolnová (PhD) \\ Prešov University in Prešov (Slovakia) \\ E-mail address of author: \\ jarmila.zolnova@unipo.sk
}

\section{Lectors:}

\author{
Mária Vájova $(\mathrm{PhD})$ \\ Prešov University in Prešov (Slovakia) \\ Helena Orieščiková $(\mathrm{PhD})$ \\ Catholic University in Ruzomberok \\ (Slovakia)
}

Žolnová, J. (2020). Implementation of Educational Support for a Pupil with Developmental Disorder in Individual Education Plan. Különleges Bánásmód, 6. (1). 103-112. DOI 10.18458/KB.2020.1.103

\begin{abstract}
The paper aims to propose a process of development of individual educational support based on the analysis of selected items taken from the individual education plans designed for students individually integrated within mainstream primary schools. We analyzed personal files of 18 students diagnosed with developmental learning disorders and ADHD (Attention Deficit Hyperactivity Disorder). The results indicate the general formulation of interventions in educational settings.
\end{abstract}

Keywords: primary school, learning disorders, ADHD, individual education plan, educational support Discipline: pedagogy

\section{Absztrakt \\ FEJLŐDÉSI ZAVARRAL KÜZDŐ GYERMEKEK OKTATÁSI TÁMOGATÁSÁNAK MEGVALÓSÍTÁSA AZ EGYÉNI FEJLESZTÉSI TERVBEN}

A tanulmány célja, hogy javaslatot tegyen a pedagógiai megsegités előkészitésének folyamatára az általános iskolákba integrált tanulók számára kidolgozott egyéni fejlesztési tervekből kiválasztott elemek elemzése alapján. A tanulók (személyes = individuális) dokumentációjának elemzését 18 olyan tanulónál végezték el, akiknél diagnosztizáltak fejlődési tanulási rendellenességeket és ADHD-t (figyelemhiányos hiperaktivitási rendellenességeket). Az eredmények rámutatnak az általánosan megfogalmazott pedagógiai intervenciók alkalmazására az oktatási körülményekben.

Kulcsszavak: általános iskola, tanulási zavar, ADHD, egyéni fejlesztési terv, oktatási támogatás Diszciplína: pedagógia 


\section{Individual education plan}

Individual education plan (IEP) is a written document providing tools to support a student with special education needs in his or her education process. It forms an integral part of "A proposal for the education of a student with special education needs in kindergartens, primary schools, secondary schools and schools for children with special needs" (thereafter referred to as Proposal) (Article 11 (9) of the Act No. 245/2008 on Education and Upbringing and on amendments and supplements to some acts). Other documentation included in the Proposal contain: basic information about a student and his or her parents, student's personal and social anamnesis, professional care provided before the commencement of student's school attendance, justification for student's individual inclusion within the school, reports from a special educator, psychologist and a doctor, written statement about the individual inclusion, a report on discussion about the inclusion proposal, a report on re-evaluation of the Proposal concerning a change of an education form, complex assessment of a student from previous school years, results of an initial observation and some appendices. The IEP is not internally structured.

The IEP's "purity" allows the competent authority to define individual student's support. On the other hand, it may tempt to design the IEP just for the sake of it, to keep to the letter of the law. We assume that a good planning and written elaboration of the IEP is a result of all actors in various positions working with an integrated student. Professional competencies of teaching and professional staff together with the parents' role and the student's needs are crucial in determining a content of the individual education plan (Žolnová In Hrebeňárová et al. 2015).

There are three phases of development and evaluation of the IEP:

- preliminary phase - identification of special educational needs, goal setting;
- the phase of IEP implementation - working towards the goals in an educational setting;

- final phase - annual evaluation.

In the preliminary phase, the support team meets for the first time and identifies the needs of a student with special educational needs. Important is to know a student's history, his or her professional educational and medical diagnostics from information provided by parents and professionals from counselling centres. No less important is a study of personal and pedagogical documents and reevaluation of the IEP from the previous school year. The first meeting should be, in our opinion, attended by a class teacher, another teacher, special education teacher, and a student's parent. In the process of the IEP development, we set and define educational goals that a student should achieve using special and compensation aids, and methods of special education teaching. At the first meeting, the support team focuses on personnel and time management and on provision of certain conditions (spatial too) needed for successful education.

When developing supportive learning environment, it is important to address these questions: will the created support benefit the student, will his or her social interaction with peers improve, what budget is needed to create a support service (cf. Dubayová, Hrebeňárová 2011; Hrebeňárová 2015).

The implementation phase is a dynamic process in which tasks are performed in order to achieve set goals. The IEP is also a tool to record any new discovered facts, changes, and evaluations. Members of the support team must answer the following questions: Do I use the support resources effectively? Do I make progress in fulfilling the set goals? Do parents see the progress too? Does the progress have individual value for a particular student? Does his or her individual progress affect their peers? What short-term objective need to be addressed? What other assessment tools can we use? 
All members of the support team should regularly discuss answers to these questions. The final phase is an annual evaluation of the IEP at the end of each school year. The support team summarizes the achieved results and analyses any risk factors. The outcomes are reported as developmental changes, stagnation, or regression of student's competencies. The IEP then serves as a foundation showing the history of development of student's competencies and any interventions or support given to him or her for the following school year (Doležal, Krátky, Cingl 2013; Žolnová 2014, 2015).

\section{Description of selected items of the individual education plan}

The IEP is a summary of goals and procedures compiled by professionals in cooperation with student's parents in order to help the student to achieve his or her educational goals. The goal setting is dependent on the educational process. The goals must be measurable and show the progress of an integrated student. "These are specific goals that define a level of educational competence and behaviour that a student must achieve" within a certain time frame. When defining them, we follow from taxonomies of educational, affective, and psychomotor objectives (Zelina 1996). Reaching a consensus on student-specific outcomes is a result of professional discussion among all members of his or her support team. Short-term and long-term goals are set.

The set goals need to be:

- consistent - short-term goals must be subordinate to long-term goals;

- adequate - align the goals with the student's abilities;

- expressed in the student's performance - describe the final state;

- clear - there is only one interpretation of the goal;
- measurable - accomplished results are compared with the set goals.

Operationalizing the goals means using active verbs. Active verbs can be either operationalized from the taxonomic concepts or they correspond with the final state. They are:

- verbal (respond, articulate, modify, convince, discuss, debate, explain, retell, repeat);

- contrast/compare (summarise, distinguish, determine, recognise, find relationship, exemplify, formulate, choose, resolve);

- musical (listen, interpret, play, amplify);

- intrapersonal approach (defend, modify, analyse, appraise, assess, contribute) (Turek 2008; Bahuand, Epp, Hall et al. 2010).

A long-term goal can be transformed into a different number of short-term goals. It is up to the support team to assess and justify the reasons for their choice.

\section{Support of a student with developmental disorders}

Inclusion is an educational system that respects the personality of the student. It allows students to attend regular school facilities. In inclusive schools, there is an individual approach for every child, and teachers pay attention to the involvement of parents as well in teaching and various projects, in order to teach children to communicate with other people. In such facilities, the difference between children is seen as an opportunity to develop respect for themselves and others. There are no two different groups of students, but children and adolescents with different needs only; many of these needs relate to the majority and create common educational and training needs. All students also have individual needs, including those whose if should be satisfied, it requires the use of special means and methods (Orieščiková, 2016). 
School must meet certain requirements to provide favourable conditions for successful learning. The least restrictive environment is a key of successful inclusive education. Schools create for every student an environment, which provides him or her with possibilities to develop and is the least restrictive for that student (Mastropieri and Scruggs, 2007, In Hrebeňárová 2015). School management should provide professional staff and create a support team for the student integrated in a mainstream school setting. According to Act No. 317/2009 Coll. on Teaching and Professional Staff and on amendments and supplements to some acts, professional staff includes a school psychologist, a school speech therapist, a school special education teacher, therapeutic and social pedagogue. The support team comprises also other teaching staff who are actively involved in developing the IEP and participate in the education of an individually integrated pupil.

The school provides material resources for supportive education. The most common items include: paper, printer toner, special relief paper, markers, highlighters, and binders. Important is to provide a technical support for working with texts, such as screen readers, reading pens, computer assistive technology, communication wireless phoneme system, computer magnification program, voice synthesis scanner, voice controlled computer, computer dictation program, etc. Using special or alternative course books, workbooks, and exercise books and writing devices is also necessary. The teacher is a key actor in the education of a pupil with a developmental disorder. He or she must be able to plan and align educational goals with specific needs of an individual pupil. Teamwork in the development and evaluation of the IEPs is crucial. Teachers then develop their communication and diagnostic competencies and learn about special pedagogical interventions and professional psychological approach to a pupil. They learn about a va- riety of professional approaches than can be used to the same educational reality.

Pasch, Garnier et al. (1998) propose to apply certain strategies to the teaching of all pupils, including those who are integrated. This way a teacher does not draw unnecessary attention to an individually integrated pupil. Instead, when assessing integrated pupils, teachers use criterion-referenced forms of evaluation; they do not compare these pupils with other children and certainly they should not jump to any hasty or unfounded conclusions about them. A teacher must recognise the strengths of every pupil and then use these strengths in group or individual activities corresponding with their educational needs.

\section{Methodology}

The analysis of selected content and formal aspect of the IEP's development aimed to answer the main research question: What particularities of selected aspects of supportive school environment are mentioned in the preliminary phase of the IEP's development? In the context of content analysis, we were mostly interested in identification of educational goals and proposed support educational services.

The main sample of pupils individually integrated in the mainstream primary school setting into the school years of 2016/2017 and 2017/2018 comprised 28047 pupils with disabilities (Annual Report of the Statistical Office, 2019). We selected 18 pupils individually integrated in the mainstream education in the regions of Prešov, Košice, Žilina, and Bratislava (following consultations and recommendations of counselling centres).

All of the selected pupils attended the first level of primary education. The sample was comprised in cooperation with competent staff of individual primary schools who granted the permission to analyse the IEPs of these pupils. One of the pupils was a $1^{\text {st }}$ grader, fourteen of them were $2^{\text {nd }}$ graders while the remaining three pupils were $3^{\text {rd }}$ graders. 
The written records of professional examinations (provided by neurologists, special education teachers, psychologists) show comorbidity of primary developmental disorders such as ADHD (attention deficit hyperactivity disorder), ADD (attention deficit disorder), hyperkinetic disorder, learning disabilities (dyslexia, dyscalculia, dysgraphia, dyspraxia and dysorthography) or developmental language disorder (developmental dysphasia) in 17 respondents.

In one case, it was a comorbidity of ADHD and cerebral palsy. One respondent had communication difficulties - it was a speech difficulty, which was not specified and manifested itself as avoiding social communication with other classmates. Problem behaviour was analysed from the reports that described such behaviour based on observations in the classrooms. The problematic behaviour was classified as follows:

- interpersonal violent behaviour - aggression;

- behaviour towards primary school authorities - lack of interest in learning, refusing to write, no homework, truancy, breaking rules, rebellion (cf. Širůčková 2015).

These are unspecified manifestations of problem behaviour, which can be secondary symptoms of the primary disorder

\section{Results of IEPs analysis}

Table 1 shows the results of individually analysed items. The individual items are then described in more detail.

\section{Analysis of the item: Educational goal setting and Educational goals for individual subjects}

In ten out of eighteen IEPs there were no set goals at all. In eight IEPs the goals were defined very formally such as: "The educational goal is for a pupil with special educational needs to complete the grade." In each of them, the particular grade of a pupil's schooling was mentioned. When individual subjects are concerned, the goals were set to address only teacher's performance: "to give a pupil tasks he or she can manage to complete", "to respect a pupil's pace", "to set short-term didactic objectives that a pupil is able to fulfil in a real time", to provide positive models of behaviour", "be patient and calm when working with a SEN pupil”.

Table 1: Results of analysed items of 18 IEPs. Source: own elaboration

\begin{tabular}{|c|c|c|c|}
\hline \multirow{3}{*}{$\begin{array}{l}\text { Education goals } \\
\text { which were to } \\
\text { be achieved by a } \\
\text { pupil }\end{array}$} & 1 & $\begin{array}{l}\text { Goals were set to suit } \\
\text { the individual pupil }\end{array}$ & 0 \\
\hline & 2 & $\begin{array}{l}\text { Formal statement of } \\
\text { general goals }\end{array}$ & 8 \\
\hline & 3 & Missing goals & 10 \\
\hline \multirow{3}{*}{$\begin{array}{l}\text { Particular edu- } \\
\text { cational goals } \\
\text { for individual } \\
\text { subjects }\end{array}$} & 1 & $\begin{array}{l}\text { Set to suit the indi- } \\
\text { vidual pupil }\end{array}$ & 0 \\
\hline & 2 & General & 8 \\
\hline & 3 & Missing or unsuitable & 10 \\
\hline \multirow[t]{3}{*}{$\begin{array}{l}\text { Educational } \\
\text { support }\end{array}$} & 1 & $\begin{array}{l}\text { Concrete } \\
\text { methods, } \\
\text { were set }\end{array}$ & 10 \\
\hline & 2 & General information & 8 \\
\hline & 3 & Missing information & 0 \\
\hline \multirow[t]{3}{*}{$\begin{array}{l}\text { Assessment and } \\
\text { grading }\end{array}$} & 1 & $\begin{array}{l}\text { The manner of as- } \\
\text { sessment and grading } \\
\text { were specified }\end{array}$ & 2 \\
\hline & 2 & General information & 16 \\
\hline & 3 & Missing information & 0 \\
\hline \multirow[t]{3}{*}{$\begin{array}{l}\text { Material and } \\
\text { technological } \\
\text { support }\end{array}$} & 1 & $\begin{array}{l}\text { Suitable given pupil's } \\
\text { special educational } \\
\text { needs }\end{array}$ & 16 \\
\hline & 2 & General & 2 \\
\hline & 3 & Not given & 0 \\
\hline
\end{tabular}

\section{Examples of how to set}

and implement concrete goals for a pupil with a developmental disorder (ADHD)

Current state: a pupil does not get his school supplies (course book, workbook, exercise book) ready for a class; when prompted by a teacher he takes out wrong items 
Result: at the start of each class, the pupil takes out different items from his or her school bag, comments his or her activity inappropriately (uses profanities), and is loud (20 September 2018).

What we need to know before goal setting: What do we want to achieve? How will we measure goal attainment? Does the pupil know colours?

Goal (short-term): In a month (by 30 October 2018) the pupil is able to choose the right supplies for each subject according to colours and put them in his or her bag at the end of each class.

Strategy: To place the items needed for each subjects in individual folders of different colours. In cooperation with parents the pupils organize a colour scheme for his or her folders for individual subjects: Slovak language, Maths, Biology, etc. The class teacher (and a teaching assistant) will be informed about this strategy (in a contact diary). The activity in the classroom will be performed with a verbal support by the teacher/teaching assistant.

Goal (long-term): By the half term, the pupils will verbally describe how he or she takes out and puts away individual items for each class.

\section{Analysis of the item: Educational support, Assessment and grading, Material and techno- logical support}

In all analysed IEPs, we found a grade and a curriculum according to which were the integrated pupils taught. In five IEPs, we found an exemption from the subject of Slovak language and literature. Thirteen IEPs informed about some changes in the curriculum: "The pupil follows an individual curriculum is accordance with the State Education Program and the School Education Program for the second (third) grade, which will be reviewed half-yearly and subsequently modified by individual teachers. The education program for pupils with ADHD for primary and lower secondary education. Approved by the Ministry of Education, Science, research and Sport of the Slovak Republic on
3 August 2017 under No.2017/10211-2:10G0, effective as of 1 September 2017". According to one of the IEPs, the pupil did not need any reduction of curricular content given his diagnosis: "The pupil is able to advance together with non-integrated pupils at the same pace". The organization of the education process was modified as: "education in a form of individual integration in a regular classroom", "the pupil will be educated together with his class, except for two classes weekly (Tuesday and Thursday) when the pupils will be taught by special education teacher individually (outside of the classroom)". The two classes were not specified in the IEP. 12 IEPs informed that the pupil would be educated in a form of school integration. The IEPs contained certain requirements that address specific needs of individual pupils: "allow a pupil to rest when tired and deconcentrated", "assign a place which will not disrupt the pupil and distract attention", "slow the pace when the child is tired", "in case of increased excitement during the class (affective display of hot temper) let the pupil calm down and keep him/her occupied by a motivational activity, or an activity that is different from that of other classmates". One of the IEPs stated: "To respect all recommendations of the Centre for Special Education Counselling". Another IEP contained specific recommendations: "In all subjects to take into account pupil's special educational needs, individual approach (the extent of individual intervention is left to a particular teacher), repeat the instructions more often, make sure the pupil understood and made notes of important things, improve concentration by dividing the assignment into shorter time intervals, make sure that the pupil correctly understood the presented information, instructions ort assignments, change activities more often, opt for short breaks, respect the pace, less tasks in written tests (even by half), short (5 min) tests are absolutely unsuitable, should be given the opportunity to redo the badly written test, examine at the beginning of a class is not recommended". 
The class teacher's support is based on certain principles, he or she were to follow during the classes: „thoughtful attitude with positive motivation”, alternating activities to attract attention", "alternating tasks demanding increased attention with relaxing moments", "assigning tasks that the pupils are able to complete", "maintain intense eye contact", "apply the "stop rule".

Three IEPs included a social support of a teaching assistant. Assessment and grading is a part of pupil's support and was mentioned in all 18 IEPs. Sixteen of them were rather formal in their proposed form of assessment and referred to current legislation. "Assessment and grading in accordance with the Article 55 (4) of the Act No. 245/2008 Coll., and the Methodological Guideline No. 22/2011 on Grading pupils in primary education, effective as of 1 May 2011, No. 20113121/12824:4-921, annex No.2 of the State Education Program for the second level of primary education in the Slovak Republic ISCED 2 - lower secondary education, education program for pupils with developmental learning disorders CD-200818550/39582-1:914 and the education program for pupils with ADHD CD2008-18550/39582-1:914“. Only in two IEPs was this information elaborated further and addressed concrete methods of assessment fostering pupil's success such as praise, positive appraisal of every even the smallest progress, positive comments about pupil's effort and diligence.

When material and technical support is concerned three IEPs contained using electronic aids: "considering the need, the pupil may use tablet", "the pupil should use a computer in all subjects", "the pupil should use a special educational program for Slovak and English language learning." However, these programs were not named. The most represented was the support in a form of special education aids: a reading window, a reading chart for dyslexics, picture alphabet, hard and soft cubes, a buzzer to distinguish between a short and long vowels, modification of curriculum with no further specification, a table of grammar rules, multiplication tables, a table of selected verbs, work sheets accommodating the individual needs of a pupil.

\section{Examples \\ of educational support implementation}

Educational support for individually integrated pupils is aimed at the development of their individual needs, so that they can attain desired competencies. Managing the support can be directed towards adjusting the environment, knowledge attainment and assessment, learning styles, social functioning within a classroom, usage of support technologies and services. What follows are the examples of a teacher's support in the inclusive setting, adapted according to Dower (2005).

It is aimed at effective description of support in a teaching process, the learning style of the particular pupil, adaptation of educational setting, forms of instruction, working habits, exam preparation, participation of classmates in the learning process.

A general description of the support received by the pupil: adaptation of curriculum, special education, plan of behaviour/intervention, other than official state language, all subjects/individual subject, medical rehabilitation, etc.

Learning styles: visual, auditory, verbal, other.

Forms of instruction that have proven successful: working in a small group, cooperative learning, practice in real-life situations, individual work, working on computers, discussions, assistive technologies, working in a large group, lecture/practical lessons, field work, one on one tutoring, age heterogeneous group, practical training, other.

Tried and tested modifications of learning conditions: extended time, reading aloud, working with material in parallel, making notes, highlighting the text, shorter recordings, adapting tests, reminding homework, modification of material, jigsaws, games, oral exams, learning in advance, reduce 
goals in the class, teaching assistants, use of computers, visual aids, parallel instructions, grading, verbal assessment, notebook notes, use of a calculator.

Classroom seating: further from a door, further from a friend, close to a friend, further from a window, close to a teacher.

Effective work habits: works best in a structured class, needs movement, easily distracted by sounds, needs encouragement, needs step-by-step instructions, needs help organizing, usually completes tasks, but needs more time.

Best learning setting: works alone with one classmate, works in a group, works with an adult, works in various settings.

Learning styles: learns from a blackboard, learns from a printed material, obtains information from a presentation, obtains information from videos and films, learns by demonstration, learn by verbal retelling, reads with comprehension, learns by discussions in the classroom, learns from graphs, pictures, learns from audio recordings, learns from practice, learns by experimenting, learns by arranging information into models, memorizes, a parent engages in learning, learns by writing, other ways of learning.

Information obtains from course books, explanations, demonstrations, worksheets, video recordings, practical experience, observations, lectures, discussions, experiments, audio recordings, and questioning and other sources of information.

Preparation before tests, exams: from notes, a course book, a workbook, worksheets, a handbook, and oral examinations.

\section{Conclusion}

The presented results of IEP's items analysis point to more or less formal approach of a support team in the preliminary phase of IEP development. Setting concrete short-term or long-term goals that the pupil should achieve is lacking significantly.
The results indicate the support by which the teachers want to eliminate learning difficulties arising from the developmental learning disorders and ADHD. They focused their attention on factors of supportive school environment, such as social, material, and technical support. A strategy of IEP development is a concept of individual support for a particular pupil, which was rather formal in all eighteen IEPs. Based on the assessed knowledge we propose the educational domains that should be considered when designing IEP to support a pupil with developmental disorder in inclusive classrooms

The paper is a partial outcome of the VEGA project No. 1/0684/19 entitled Evaluation of Behavioural Interventions in Education of Children and Pupils with Autism Spectrum Disorder and Other Developmental Disorders.

\section{References}

Bahuaud, M., Epp, B., Hall, R. et al. (2010). Student-specific planning: handbook for developing and implementing individual education plans (IEPs). [online]. Canada: Manitoba Education, 2010. [cit.12.02.2019]. retrieved from:

$<$ www.edu.gov.mb.ca/k12/specedu/iep/pdf/plan ning/cover_ack_intro.pdf $>$ ISBN 13: 978-0-77114461-5.

Doležal, Jan, Jiří Krátky \& Ondřej Cingl (2013). 5 krokũ k úspěsnému projektu. Bratislava: Grada. ISBN 978-80-247-4631-9.

Dover, Wendy, F. (2005). The classroom teacher's guide: to instructional and curricular modifications. Manhattan, Kansas: The Master Teacher, Inc, 112 p. ISBN 1-58992-219-0.

Dubayová, Tatiana \& Lucia Hrebeňárová (2011). Etické dilemy $\mathrm{v}$ špeciálnej pedagogike. In: Aadland, E., Matulayová, T. (eds). Etické reflexie v pomáhajúcich profesiách. Prešov: Vydavatel'stvo 
Prešovskej univerzity, pp. 81-103. ISBN 97880-555-0331-8.

Metodický pokyn č.22/2011 na hodnotenie žiakov ZŠ platný od 1. mája 2011, č.: 20113121/12824:4-921. [online]. Bratislava: MŠVVaŠ SR. [cit. 5.12.2018]. retrieved from: https://www.minedu.sk/metodicky-pokyn-c222011-na-hodnotenie-ziakov-zakladnej-skoly/

Hrebeňárová, Lucia (2015). Inkluzívna edukácia žiakov s viacnásobným postihnutím. In: Hrebenárová, Lucia a kolektív. Vybrané oblasti inkluzínnej edukácie žiakov so špeciálnymi výchounov₹delávacimi potrebami $v$ primárnom v₹delávaní. Prešov: Vydavatel'stvo prešovskej univerzity $\mathrm{v}$ Prešove. ISBN 978-80-555-1457-4.

Mastropieri, M. A., Scruggs, T. E. (2007). The inclusive classroom. Strategies for effective instruction. Upper Saddle River, New Jersey: Pearson, 2007. In: Hrebeňárová, Lucia, 2015. Inkluzívna edukácia žiakov s viacnásobným postihnutím. In: Hrebeňárová, Lucia a kolektív. Vybrané oblasti inkluzívnej edukácie žiakov so špeciálnymi výchovno-vzdelávacími potrebami v primárnom vzdelávaní. Prešov: Vydavatel’stvo prešovskej univerzity v Prešove. ISBN 978-80555-1457-4.

Návrh na prijatie žiaka so špeciálnymi výchovnovzdelávacími potrebami do špeciálnej školy, do špeciálnej materskej školy, do základnej školy a do strednej školy. [online]. Bratislava: ŠPÚ. [cit. 15.12.2018]. retrieved from: http://formulare.uips.sk/

Orieščiková, H. (2016). Integrácia: čo s ňou? Ružomberok: Verbum - vydavatel'stvo Katolíckej univerzity v Ružomberku. 101 s. ISBN 978-80-561-0419-4.

Širůčková, Michaela (2015). Rizikové chování a jeho psychosociální souvislosti. In: Miovský, Michal a kol. Prevence rizikového chování ve školství. Praha: UK v Praze, 1. lekářska fakulta, Klinika adiktológie. ISBN 978-80-7422-392-1.
Štatistická ročenka. [online]. Bratislava: CVTI SR. [cit. 5.2.2019]. retrieved from: http://www.cvtisr.sk/cvti-sr-vedeckakniznica/informacie-o-skolstve/statistiky /statisticka-rocenka-publikacia/statistickarocenka-specialne-skoly.html?page_id $=9600$

Pasch, M., Garnier, T., G. et al. (1998). Od vzdělávacího programu $\mathrm{k}$ vyučovací hodine. Praha: Portál, p. 416.

Vzdelávací program pre žiakov s poruchami aktivity a pozornosti pre primárne vzdelávanie a nižšie stredné vzdelávanie. Schválilo Ministerstvo školstva, vedy, výskumu a športu Slovenskej republiky dňa 03. 08. 2017 pod číslom 2017/10211-2:10G0 s platnost'ou od 1. septembra 2017. [online]. Bratislava: ŠPÚ. [cit. 5.1.2019]. Retrieved from: http://www.stat pedu.sk/files/sk/deti-ziaci-so-svvp/deti-ziaciso-zdravotnym-znevyhodnenim-vseobecnymintelektovym-nadanim/vzdelavacie-programy/ Vzdelávací program pre žiakov s vývinovými poruchami učenia. Schválilo Ministerstvo školstva, vedy, výskumu a športu Slovenskej republiky dňa 5. 5. 2016 pod číslom 201614674/20281:15-10F0 s platnost'ou od 1. 9. 2016 [online]. Bratislava: ŠPÚ. [cit. 4.1.2018]. Retrieved from: http://www.statpedu. sk/files/sk/deti-ziaci-so-svvp/deti-ziaci-sozdravotnym-znevyhodnenim-vseobecnymintelektovym-nadanim/vzdelavacieprogramy/vzdelavacie-programy-ziakov-sozdravotnym-znevyhodnenim-vseobecnymintelektovym-nadanim/zakladne-vzdelavanieprimarne-vzdelavanie-nizsie-stredne vzdelavanie/vp_pre_ziakov_s_vyvinovymi_porucham i_ucenia.pdf

Turek, Ivan (2008). Didaktika. Bratislava: Iura Edition.

Zelina, Miron (1996). Stratégie a metódy rozuoja osobnosti diet'at'a. Bratislava: Iris. 
Žolnová, Jarmila (2014). Diet’a s problémovým správanim v materskej škole. Prešov: Prešovská univerzita v Prešove. ISBN 978-80-555-1127-6.

Žolnová, Jarmila (2015). Individuálny vzdelávací program pre žiaka individuálne začleneného $\mathrm{v}$ škole hlavného prúdu. In: Hrebeňárová, Lucia a kolektív. Vybrané oblasti inkluzívnej edukácie žiakov so špeciálnymi výchovno-vzdelávacími potrebami v primárnom vzdelávaní. Prešov: Vydavatel'stvo prešovskej univerzity v Prešove. ISBN 978-80-555-1457 